\title{
Penggunaan Teknik Discovery Dengan Media Gambar Untuk Membangkitkan Minat Belajar Siswa
}

\author{
Susana Engsa', Sri Rejeki² \\ ${ }^{1}$ Pendidikan Pancasila dan Kewarganegaraan, Universitas Muhammadiyah Mataram, susanaengsa11@gmail.com \\ ${ }^{2}$ Pendidikan Pancasila dan Kewarganegaraan, Universitas Muhammadiyah Mataram, umi.cici.66@gmail.com
}

INFO ARTIKEL
Riwayat Artikel:
Diterima: $\quad$ 15-Agustus-
2018
Disetujui: 18-September-
2018

\section{Kata Kunci:}

discovery

media

gambar

minat

belajar

\begin{abstract}
Abstrak: Proses belajar di Sekolah Menengah Pertama Negeri 19 Mataram diketahui belum signifikan dilihat dari segi minat belajar siswa sangat kurang sehingga berdampak pada minimnya prestasi belajar siswa. Selain itu guru juga harus menggunakan teknik dengan barbagai cara agar siswa berperan aktif dalam proses belajar seperti guru menggunakan media gambar supaya siswa tidak jenuh dalam proses belajar mengajar langakah-langkah tersebut memerlukan partisipasi aktif dari siswa. Tujuan penelitian ini untuk mendeskripsikan pengaruh penggunaan teknik discovery dengan media gambar untuk membangkitkan minat belajar siswa pada mata pelajaran PPKn kelas VII di SMPN 19 Mataram. Jenis penelitian yang digunakan dalam penelitian ini adalah penelitian kuantitatif, dengan pendekatan eksperimen. Metode pengumpulan data menggunakan metode observasi, dokumentasi, dan angket dengan metode analisis data korelasi product moment. Hasil penelitian menunjukkan berdasarkan analisis data yaitu. Hasil analisis data yang di peroleh dalam adalah 0,574, dengan taraf signifikan $5 \%$, maka diperoleh nilai 0,300 . Jadi nilai $r$ perhitungan lebih besar dibandingkan dengan nilai $r$ tabel $(0,574>0,300)$. Jadi hipotesis $(\mathrm{Ha})$ adalah, "Adanya Pengaruh Penggunaan Teknik Discovery Dengan Media Gambar Membangkitkan Minat Belajar Siswa Kelas VII SMPN 19 Mataram Pada Bidang Studi PPKn Tahun Pelajaran 2017$2018^{\prime \prime}$ diterima.
\end{abstract}

ABSTRAK

\begin{abstract}
The learning process at the state Junior high School 19 Mataram is known to have not been significantly seen in terms of learning the interest of the students very less so it affects the lack of student learning achievement. In addition, teachers also have to use techniques as a way for students to play an active role in learning processes such as teachers using image media so that students are not saturated in the process of learning the steps are requiring participation Active from students. The purpose of this research is to describe the influence of the use of discovery techniques with image media to generate interest in students ' study in class VII SMPN 19 Mataram. The type of research used in this study is quantitative research, with an experimental approach. Methods of collecting data using observation methods, documentation, and polls with data analysis method correlation product moment. The results showed based on data analysis ie. The results of the analysis of data obtained in the 0.574 , with a significant status of $5 \%$, then obtained the value of 0.300 . So the value of $R$ calculation is greater than the value of the $R$ table $(0,574>0,300)$. So hypothesized $(\mathrm{Ha})$ is, "the influence of the use of Discovery techniques with Media image generating interest learning students grade VII SMPN 19 Mataram in the field of the study year 2017-2018" received.
\end{abstract}

\section{A. LATAR BELAKANG}

Pendidikan adalah usaha sadar dan terencana untuk mewujudkan suasana belajar dan proses pembelajaran agar peserta didik secara aktif membangkitkan minat potensi dirinya untuk memiliki kekuatan spiritual, keagamaan, pengendalian diri, kepribadian, kecerdasan, akhlak mulia, serta keterampilan yang diperlukan dirinya, masyrakat bangsa dan negara. Pada mata pelajaran pendidikan kewarganegaran siswa lebih ditekankan agar menjadi warga Negara yang cerdas dan partisipatif. Dalam kegiatan pembelajaran PPKn di sekolah guru selalu menekankan kepada siswa agar berperan aktif dan partisipasif.

Tujuan pembelajaran ditentukan oleh banyak faktor diantaranya adalah faktor guru, karena guru memiliki peranan yang sangat penting dalam menentukan kuantitas dan kulitas pengajaran yang dilaksanakan. Oleh sebab itu, guru harus memikirkan dan membuat perencanaan secara seksama dalam membangkitkan kesempatan dan minat belajar siswa serta membangkitkan kualitas mengajaranya.

Hal ini menuntut perubahan-prubahan dalam mengorganisasikan kelas, penggunaan metode mengajar, strategi belajar mengajar, maupun sikap dan 
karakteristik guru dalam mengelolah proses belajar mengajar. Guru berperan sebagai pengelola proses belajar mengajar, bertindak sebagai fasilitator yang berusaha menciptakan kondisis belajar mengajar yang efektif, sehingga memungkinkan proses belajar mengajar, mengembangkan bahan pelajaran dengan baik, dan mengembangakan kemampuan siswa untuk menyimak pelajaran dan menguasai tujuan-tujuan pendidikan yang harus mereka capai.

Untuk memenuhi hal tersebut di atas, guru dituntut mampuh mengelolah proses belajar mengajar yang memberikan rangsangan kepada siswa karena siswalah subiyek utama dalam belajar. Mengajar adalah memimbing belajar siswa sehingga mamapu belajar. Dengan demikian aktifitas siswa sangat diperlukan dalam kegiatan belajar mengajar sehingga siswalah yang seharusnya banyak aktif, sebab siswa sebagai subiyek didik adalah yang merencanakan, dan ia sendiri yang melaksanakan belajar. Pada kenyatan, disekolah-sekolah seringkali guru yang aktif, sehingga siswa tidak diberi kesempatan untuk aktif maka, perlu adanya media gamabar dalam kegiatan pembelajaran di kelas.

Media pembelajaran adalah segalah sesuatu yang dapat digunakan untuk menyampaikan pesan atau informasi dalam proses belajar mengajar sehingga dapat merangsang perhatian dan minat siswa dalam belajar[1]. Lebih lanjut Gaggnes and Briggs[2] dalam Arsyad secara eksplisit mengatakan bahwa media pembelajaran meliputi alat yang secara fisik digunakan untuk menyampaikan materi pembelajaran alat ini dapat berupa alat-alat grafis, visual, elektronis dan audio yang digunakan untuk mempermudah informasi yang disampaikan kepada siswa[1]. Sedangkan media gambar adalah media yang berfungsi untuk menyampaikan pesan melalui gambar yang menyangkut indra pengelihatan[3]. Pesan yang disampaikan dituangkan melalui simbol-simbol komunikasi visual. Media gambar mempunyai tujuan untuk menarik perhatian, memperjelas materi, mengilstrasikan fakta dan informasi.

Berdasarkan hasil observasi bahwa proses belajar di SMP Negeri 19 Mataram mengetahui perubahan yang belum signifikan tentang minat belajar siswa sangatlah kurang sehingga berdampak pada minimnya prestasi belajar siswa. Selain itu guru juga harus menggunakan teknik dengan barbagai cara agar siswa berperan aktif dalam peroses belajar seperti guru menggunakan media gamabar supaya siswa tidak jenuh dalam proses belajar mengajar langakah-langkah tersebut memerlukan partisipasi aktif dari siswa. Untuk itu perlu adateknikpembelajaran discovery yang merupakan suatu teknikpengajaran yang menitikberatkan pada aktifitas siswa dalam belajar.

Misalkan mampu membangkitkan minat belajar pada diri siswa, memberikan kesempatan kepada siswa untuk berkembang dan maju sesuai dengan kemampuan masing-masing, membantu siswa mengembangkan, memperbanyak kesiapan serta penguasaan keterampilan dalam kogknitif atau pengarahan siswa, siswa memperoleh pengetahuan yang bersifat sangat peribadi atau individual sehingga dapat kokoh atau mendalam tertinggal dalam jiwa siswa tersebut.

Di dalam peroses pembelajaran dengan penggunaan teknik discovery dengan media gambar ini, guru hanya bertindak sebagai pembimbing dan fasilitator mengarahkan siswa untuk menemukan konsep, dalil, dan prosedur. Untuk itu diperlukan suatu upaya dalam rangka membangkitkan minat pendidik dan pengajaran salah satunya adalah dengan memilih strategi atau cara dalam menyampaikan materi pelajaran agar diperoleh membangkit minat belajar siswa. Dengan membimbing siswa untuk bersama-sama terlibat aktif dalam proses pembelajaran dan mamapu membantu siswa berkembang sesuai dengan taraf intelektualnya akan lebih menguatkan pemahanman siswa terhadap konsep yang diajarkan. Penerapan metode pembelajaran yang kurang tepat yaitu pembelajaran yang masih cendrung berpusat pada guru sehingga siswa kurang aktif dalam proses pembelajaran. Seseorang guru dalam menyampaikan materi perluh memilih teknik sehingga siswa merasah tertarik untuk mengikuti pelajaran yang akan diajarakan.

Siswa sebagai obyek atau penerima dalam proses pembelajaran oleh karena itu perlu digunakan sebuah teknik discovery yang dapat membantu siswa untuk memperbaiki dan meningkatkan keterampilanketerampilan dan proses-proses kognitif. Pengetahuan yang diperolehmelalui teknik ini sangat pribadi karena menguatkan pengertian ingatan dan transfer.

Suasana pembelajaran di kelas akan lebih menarik jika guru menyampaikan materi melalui media pembelajaran, manfaat media pembelajaran adalah proses pembelajaran yang lebih jelas dan menarik, proses pembelajaran lebih interaktif dapat mengefesienkan waktu, dan dapat meningkatakan hasil belajar siswa[4]. Salah satu media pembelajaran yang dapat digunakan yakni media audio visual. Sementara media audio visual adalah media yang mempunyai unsur suara dan unsur gambar bisa dilihat, misalnya rekaman video, berbagai ukuran film, slide suara, dan sebagainaya[5]. Di lihat dari perkembangan mediaaudio visual bisa diakatakan sangat ampuh menyampaikan suatu pesan terhadap orang banyak dari pada mediamedia lain. Audio visual merupakan salah satu media yang mengungkapkan objek atau peristiwa seperti keadaan sesungguhnya karena dengan adanya media gambar audio visual siswa lebih mudah memahami pesan dalam pembelajaran PPKn secara lebih bermakna sehingga informasi yang disampaikan melalui media gambar audio visual tersebut dapat dipahami dengan mudahdan siswa diharapkan mampu menerima 
pelajaran PPKn dengan mudah dan guru sebagai fasilitator.

Melihat uraian singkat diatas maka peneliti membahas tentang permasalah yang ada di SMP Negeri 19 Mataram yang dimana masih kurangnya partisipasi siswa dalam kegiatan pembelajaran maka dari itu perlunya kerja sama antara siswa dan guru,yaitu dengan menggunakan teknik discovery kuhsusnya media gambar. Oleh karena itu guru harus berperan aktif dalam proses pembelajaran agar siswa tidak pasif supaya dapat berjalan secara bersamaan dalam pembelajaran. Permasalahn lain yaitu kurangnya hubungan timbal balik antara guru dan siswa yang beraneka ragam, dan itu akan mengakibatkan rendahnya pengetahuan yang dimiliki oleh siswa. Dengan menggunakan teknik discovery khususnya media gambar dalam proses belajar mengajar guru harus menguasai prinsip-prinsip belajar serta mampu menerapkan teknik yang digunakan seperti media gambar yang tepat untuk suatu materi pembelajaran PPKn.

Media gambar mampu meberikan detail dalam bentuk gambar apa adanya, sehingga siswa dapat dengan mudah untuk mengingatnya. Media ini merupakan bahasa yang umum, dan dapat dimengerti, dinikmati oleh semua orang dimana-mana[3]. Selain itu media gambar juga bersifat kongkret, mengatasi keterbatasan pengamatan, memperjelas suatu sajian masalah, mudah didapat dan bisa digunakan dengan mudah[6]. Oleh karena itu, dengan menggunakan media gambar tentunya membantu siswa dalam kegiatan pembelajaran.

Foto merupakan alat fisual yang efektif karena dapat menfisualisasikan sesuatu yang akan dijelaskan dengan lebih konkret dan realistis. Foto merupakan salah satu media pembelajaran yang amat dikenal di setiap pembelajaran[7]. Informasi yang disampaikan dapat dimengerti dengan mudah karena hasil yang diragakan lebih mendekati kenyataan melalui foto atau gambar yang diperlihatkan kepada anak-anak. Foto dapat mengatasi ruang dan waktu, sesuatu yang terjadi ditempat yang lain dapat dilihat oleh orang berada jauh dari tempat kejadian dalam bentuk setelah kejadian itu berlalu. Dengan adanya media foto siswa dapat mengingat kembali tentang sesuatu yang pernah terjadi dalam kehidupanya, sehingga siswa dapat mengeksplorasikan ide atau gagasanya kedalam bentuk tulisan. Gambar yang baik bukan hanya dapat menyampaikan saja tetapi dapat digunakan untuk melatih keterampilan berpikir serta dapat mengembangkan imajinasi siswa[5]. Dapat disimpulkan bahwa media gambar atau foto adalah salah satu media yang sederhana, dan dapat memberikan kemudahan bagi siswa khusunya dalam pembelajaran PPKn melalui media gambar, segalah idea tau gagasan yang dimiliki siswa dapat dituangkan dengan mudah karena pembelajaran yang dilakukan terkesahan lebih bermakna.
Berdasarkan permasalahan di atas maka peneliti tertarik untuk mengkaji Penggunaan Teknik Discovery Dengan Media Gamabar Untuk Membangkitkan Minat Belajar Siswa Pada Mata Pelajaran PPKn Kelas VII di SMPN 19 Mataram. Berdasarakan latar belakang diatas permasalahan yang diajukan dalam penelitian ini adalah apakah terdapat pengaruh Penggunaan Teknik Discovery Dengan Media Gambar Untuk Membangkitkan Minat Belajar Siswa Pada Mata Pelajaran PPKn Kelas VII di SMPN 19 Mataram?

\section{B. METODE PENELITIAN}

1. Jenis penelitian yang Digunakan

Adapun jenis penelitian yang digunakan dalam penelitian ini adalah penelitian kuantitatif dengan pendekatan eksperimen . Penelitian kuantitatif yaitu penelitian yang menganalisis data penelitian dengan perhitungan statistik. Penelitian ini merupakan penelitian yang data-datanya dalam bentuk angka-angka, dengan melihat realitas sebagai hal yang saling berhubungan. Berdasarkan hal tersebut, maka penelitian ini merupakan penelitian kuantitatif yang bersifat korelasional, yaitu penelitian yang dilakukan oleh peneliti untuk mengetahui tingkat hubungan antara dua variabel atau lebih tanpa melakukan perubahan, tambahan atau manipulasi terhadap data yang sudah ada[8].

Pendekatan korelasional ini digunakan untuk menentukan arah korelasi kedua variabel yang diteliti, sebagaimana dijelaskan dibawah ini.

Arah korelasi itu digolongkan menjadi tiga bagian, yakni arah korelasi positif, arah korelasi negative dan arah korelasi nihil. Arah korelasi positif dapat dijelaskan bahwa apabila variabelXmeningkat maka akan diikuti dengan meningkatkanya variabel $\mathrm{Y}$ dan sebaliknya. Sedangkan arah korelasi negative berarti apabila variabel $\mathrm{X}$ menurun maka akan diikuti dengan meningkatnya variabel $\mathrm{Y}$, demikian sebaliknya apabila variabel $\mathrm{Y}$ meningkat, maka akan diikuti dengan menurunya variabel X. Arah korelasi nihil artinya kedua variabel tidak memiliki hubungan sama sekali[9].

Dengan demikian, jika dalam penelitian ini ditemukan arah korelasi positif, akan bermakna semakin bagus kemampuan guru menggunakan metode discovery, maka semakin bagus proses pembelajaran. Sebaliknya, tidak kemampuan guru menggunakan metode discovery, maka semakin tidakbagus proses pembelajaran. Sedangkan arah korelasi negatif, artinya kemampuan guru menggunakan metode discovery, tidak bagusnya proses pembelajaran, Begitu pula sebaliknya, kemampuan guru menggunakan metode discoverymaka akan diikuti dengan bagusnya proses pembelajaran. Selanjutnya, arah korelasi nihil, artinya kedua variabel tidak memiliki hubungan .

Korelasi Pearson Product Moment dilambangkan (r) dengan ketentuan nilai $r$ tidak lebih dari harga $(-1 \leqslant r$ $\leqslant+1$ ). Apabila $r=-1$ artinya korelasinya negative 
sempurna, $\mathrm{r}=\mathrm{o}$ artinya tidak ada korelasi, dan $\mathrm{r}=1$ berarti korelasinya sempurna positif (sangat kuat). Sedangkan harga $\mathrm{r}$ akan dikonsultasikan dengan tabel interpretasi nilai r sebagai berikut:

Tabel 1

Interpretasi koefisien korelasi nilai $\mathrm{r}$

\begin{tabular}{ccc}
\hline No & Interval & Keterangan \\
\hline 1 & $0,00-0,199$ & Sangat tinggi \\
2 & $0,20-0,399$ & Tinggi \\
3 & $0,40-0,599$ & Cukup \\
4 & $0,60-0,799$ & Rendah \\
5 & $0,80-1,000$ & Sangat rendah \\
\hline
\end{tabular}

\section{Lokasi Penelitian}

Lokasi penelitian ini dilkaukan pada SMPN 19 MataramTahun ajaran 2017/2018, yang terletak di jalan Jln. Dr. Soedjono Lingkar Selatan Dasan Cermen Sandubaya Kota Mataram.

3. Metode Penentuan Populasi

a. Populasi

Populasi adalah keseluruhan subjek penelitian[8]. Apabila seseorang ingin meneliti semua yang ada dalam wilayah penelitian, maka penelitinya merupakan penelitian populasi. Populasi diartikan sebagai wilayah generalisasi yang terdiri atas: Obyek/subyek yang mempunyai kualitas dan karakteristik tertentu yang ditetapkan oleh peneliti untuk dipelajari dan kemudian ditarik kesimpulannya[10].

Sehubungan dengan uraian di atas, yang menjadi populasi dalam penelitian ini adalah seluruh siswa kelas VII SMPN 19 Mataram Tahun Pelajaran 2017/2018 yang berjumlah 31 siswa.

\section{Tabel 2}

Data Siswa Kelas VII di SMPN 19 Mataram Tahun Pelajaran 2017/2018

\begin{tabular}{|c|c|c|c|}
\hline \multirow{2}{*}{ Kelas } & \multicolumn{2}{|c|}{ Jenis Kelamin } & \multirow{2}{*}{ Jumlah } \\
\cline { 2 - 3 } & $\begin{array}{c}\text { Laki- } \\
\text { laki }\end{array}$ & Perempuan & \\
\hline VII $^{\text {B }}$ & 19 & 14 & 31 \\
\hline
\end{tabular}

Dengan mempertimbangkan hal-hal diatas dan melihat keadaan populasi berkelompok-kelompok yaitu sebanyak satua kelas maka dalam penelitian ini peneliti menggunakan kelas VIIB yang jumlah siswanya 31 siswa sebagaipopulasi untuk memperoleh data penelitian.

\section{b. Sampel}

Sampel adalah sebagian atau wakil dari populasi yang akan diteliti. Dalam kaitannya dengan penelitian ini, wakil yang dimaksud adalah individu-individu dari populasi siswa dengan menggunakan model pembelajaran discovery untuk minat belajar siswa[8]. Hal ini dilakukan karena terbatasnya fasilitas yang tersedia sehingga tidak memungkinkan dilakukan penelitian terhadap seluruh individu.

4. Metode Pengumpulan Data

Untuk memperoleh data yang diperlukan dalampenelitian ini, yaitu kemampuan guru menggunakan metode discovery, digunakan metode observasi, dokumentasi dan angket.

Adapun jenis-jenis metode penelitian yang digunakan dalam penelitian ini adalah :

a. Observasi

Adalah melakukan pengamatan secara langsung ke subjek penelitian untuk melihat dari dekat kegiatan yang di lakukan. Apakah obyek penelitian bersifat perilaku, tindakan manusia, dan fenomena alam (kejadiankejadian yang ada di alam sekitar), proses kerja, dari penggunaan responden besar. Observasi atau pengamatan merupakan suatu teknik atau cara mengumpulkan data dengan jalan mengadakan pengamatan terhadap kegiatan yang sedang berlangsung. Obeservasi dapat dilakukan dengan partisipasi atau non[11].

\section{b. Angket}

Angket adalah teknik pengumpulan data yang di lakukan dengan cara memberi seperangkat pertanyaan atau responden untuk dijawabnya[12]. Sedangkan pendapat lain[13] menjelaskan bahwa "angket adalah usaha untuk mengumpulkan informasi dengan menyampaikan sejumlah pertanyaan tertulis untuk dijawab tertulis pula oleh responden". Angket merupakan "suatu daftar berisi pertanyaan-pertanyaan kepada responden dengan harapan memberikan respon atas daftar pertanyaan tersebut“'[14].

Adapun keuntungan kuesioner[8] sebagai berikut:

1. Tidak memerlukan hadirnya peneliti

2. Dapat dibagikan secara serentak kepada banyak responden

3. Dapat dijawab oleh responden menurut kecepatan masing-masing dan menurut waktu senggang responden

4. Dapat dibuat anonim sehingga responden bebas,jujur dan tidak malu-malu menjawab pertanyaan.

5. Dapat dibuat standar sehingga bagi semua responden dapat diberikan pertanyaan yang benarbenar sama.

Berdasarkan pertimbangan peneliti tentang angket atau kuesioner yang akan dijadikan sebagai alat pengumpulan data, maka setelah memperhatikan jenis angket atau kuesioner dari beberapa sudut pandang maupun keuntungan tersebut diatas, peneliti berkesimpulan bahwa alat pengumpulan data yang paling tepat digunakan adalah jenis kuesioner tertutup, langsung dan pilihan ganda.

Skala yang digunakan dalam penelitian ini adalah skala likert, Adapun skala likert merupakan suatu skalapsikometrik yang umum digunakan dalam kuesioner dan merupakan skala yang paling banyak digunakan dalam riset berupa survei. Nama skala ini diambil dari nama Rensis Likert, yang menerbitkan suatu laporan yang menjelaskan penggunaannya. Sewaktu menanggapi pertanyaan dalam skala Likert, 
responden menentukan tingkat persetujuan mereka terhadap suatu pernyataan dengan memilih salah satu dari pilihan yang tersedia. Biasanya disediakan lima pilihan skala dengan format seperti:

1. Sangat Setuju (Sangat Positif) diberi skor 5

2. Setuju (Positif) diberi skor 4

3. Kurang Setuju (Negatif) diberi skor 3

4. Tidak Setuju (Sangat Negatif) diberi

skor 2

5. Sangat Tidak Setuju (Sangat Negatif) diberi skor 1

Selain pilihan dengan lima skala seperti contoh di atas, kadang digunakan juga skala dengan tujuh atau sembilan tingkat. Suatu studi empiris menemukan bahwa beberapa karakteristik statistik hasil kuesioner dengan berbagai jumlah pilihan tersebut ternyata sangat mirip.

c. Dokumentasi

Dokumentasi merupakan catatan peristiwa yang sudah berlalu[9]. Dokumentasi bisa berbentuk tulisan, gambaran, atau karya-karya monumental dari seseorang. Dokumentasi cara mengumpulkan data melalui peninggalan tertulis, seperti arsip, termasuk juga buku tentang teori, pendapat, dalil atau hukum, dan lain-lain yang behubungan dengan masalah penelitian disebut teknik dokumenter atau studi dokumenter.

Dalam penelitian ini metode dokumenentasi digunakan untuk memperoleh data penelitian terkait dengan:

1) Data keadaan Siswa SMPN 19 Mataram

2) Data keadaan Guru, Pegawai dan Karyawan SMPN 19Mataram

3) Keadaan sarana dan prasarana SMPN 19 Kota Mataram

4) Struktur organisasi SMPN 19 Mataram.

5. Jenis dan Sumber Data

a. Jenis Data

Secara umum data dikelompokkan menjadi dua yaitu:

1) Data kualitatif adalah data yang bukan merupakan angka-angka tetapi di tujukan dengan kategorikategori.

a) Data kualitatif yang dapat dikualifikasikan merupakan data kualitatif yang nilainya dapat di ukur atau dinyatakan dalam bentuk angka.

b) Data kualitatif yang tidak dapat dikualifikasikan merupakan data kualitatif yang nilainya tidak dapat diukur atau dinyatakan dalam bentuk angka.

2) Data kuantitatif adalah data yang di tentukan dengan angka-angka. Data kuantitatif di kelompokkan menjadi empat macam, yaitu

a) Data interval adalah data yang di hasilkan terdapat dari pengaturan yang didalam pengukuran itu di asumsikan terdapat satuan (unit pengukuran yang sama).

b) Data nominal adalah data yang di tentukan atau ditetapkan berdasarkan atas proses penggolongan, variabel ini bersifat deskrif dan saling pilah (mutually exclusive) antara kategori satu dengan yang lain.

c) Data ordinal adalah data yang di susun berdasarkan atas jenjang atau peringkat dalam atribut tertentu.

d) Data rasio adalah data yang dalam proses kualifikasinya mempunyai nol mutlak[10].

b. Sumber Data

Sumber data dapat dikelompokkan menjadi 2 (dua)[9]:

a. Sumber data primer adalah sumber data asli yang diperoleh secara langsung dari lapangan wawancara dengan guru. Sumber data sumber data primer dalam penelitian yang diperoleh secara langsung responden yang disesuaikan dengan tujuan penelitian.

b. Sumber data skunder adalah sumber data yang mengutip dari sumber lainya. Dalam penelitian ini maka data yang di perolehpeneliti adalah bersumber data yaitu dokumentasi yang sebarkan ke responder, dalam subjek penilitian yaitu guru dan siswa di SMPN 19 Mataram, dokumendokumen SMPN 19 Mataram dan hasil wawancara dengan segenap mengelola SMPN 19 Mataram Tahun Ajaran 2017/2018.

6. Indentifikasi dan Definisi Operasional Variabel a. Indentifikasi Variabel

Jenis variabel yang dipakai dalam penelitian dapat diidentifikasikan menjadi dua:

1) Variabel bebas adalah variabel yang mempengaruhi atau penyebab. Berdasarkan pengertian tersebut maka yang menjadi variabel bebas dalam penelitian ini adalah metode discovery.

2) Variabel terikat adalah veriabel dipengaruhi atau variabel akibat. Berdasarkan uraian tersebut, maka yang menjadi variabel terikat dalam penelitian ini adalah minat Belajar Anak SMPN 19 Mataram.

b. Definisi operasional

Perhatian utama penelitian pendidikan terletak pada pembahasan dan analisis terhadap hasil-hasil pengukuran. Pembahasan hasil penelitian ini akan menjadi lebih efektif apabila peneliti memiliki kriteria yang tepat terhadap hasil. Kriteria ini berupa batasan operasional tentang hasil. Batasan operasional ini adalah suatu bukti tentang variabel-variabel yang diteliti dan akan diterima oleh peneliti.

Variabel atau faktor penelitian memiliki peranan sangat penting dalam suatu penelitian pendidikan. Variabel adalah segala sesuatu yang akan menjadi objek pengamatan dalam penelitian. Ada juga yang menganggap variabel sebagai gejala sesuatu yang bervariasi. Adapun definisi dari kedua variabel tersebut di atas, yaitu:

1) Metode Discovey

Discovery adalah teknik pembelajaran yang menuntu siswa secara aktif melakukan pencarian pengalaman belajar menggunakan analisi dan 
pemecahan masalah yang dihadapinya dengan menemukan dan menyelidiki sendiri.

2) Minat Belajar

Minat belajar adalah kecendrungan individu untuk memiliki rasa senang tanpa ada paksaan sehinggah dapat menyebabkan perubahan pengetahuan, keterampilan dan tingkah laku. Minat belajar dapat dilihat dari nilai raport siswa dalam mata pelajaran PPKn.

7. Instrumen Penelitian

Instrumen penelitian adalah semua alat yang digunakan untuk mengumpulkan, memeriksa, menyelidiki suatu masalah atau mengumpulkan, mengolah, menganalisa dan menyajikan data-data secara sistematis serta objektif dengan tujuan memecahkan suatu persoalan atau menguji suatu hipotesis. Jadi semua alat yang bisa mendukung suatu penelitian bisa disebut instrumen penelitian. Instrumen penelitian digunakan untuk mengukur nilai variabel yang diteliti.

\section{a. Instrumen tentang Angket}

Instrumen yang digunakan untuk mengukur pengunaan metode discovery adalah angket tertutup yang dikembangkan dalam bentuk rating sacle dengan menggunakan scala likert dengan alternatif jawaban sebagai berikut: sangat setujuh untuk bobot nilai 5 , Setujuh untuk bobot nilai 4, Kurang setujuh untuk bobot nilai 3, Tidak setujuh untuk bobot nilai 2 dan Sangat tidak seutuju untuk bobot nilai 1. Adapun tabel kisi-kisi istrumen metode discovery dapat dilihat pada tabel dibawah ini.

Tabel 3

Kisi-kisi Instrumen

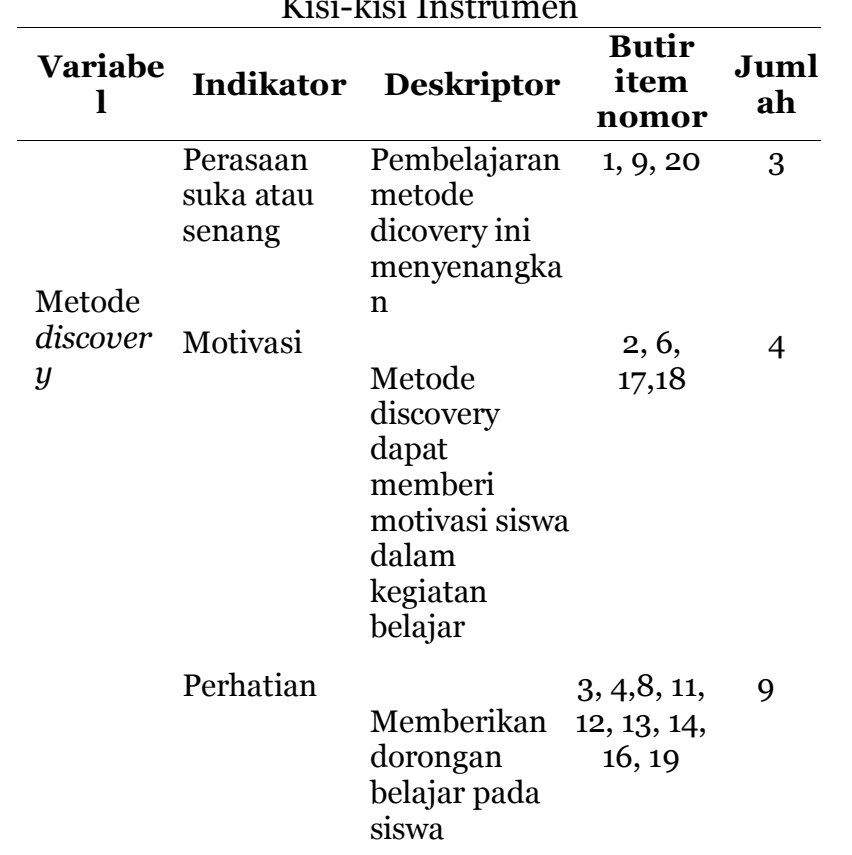

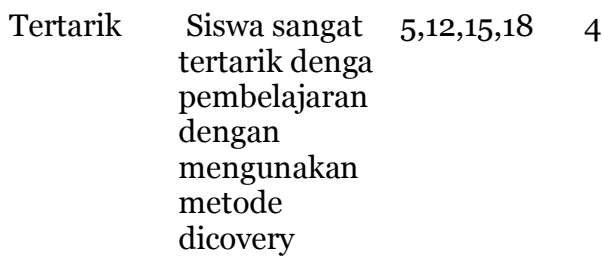

Jumlah

20

b. Validitas

Sebuah angket dikatakan memiliki validitas jika hasilnya sesuai dengan kriterium, dalam arti memiliki kesejajaran antara hasil angket tersebut dengan kriterium. Untuk mencari validitas butir nomor angket dapat dicari dengan menggunakan rumus korelasi product moment sebagai berikut (Suharsimi Arikunto, 2013: 92).

$$
r_{x y}=\frac{N \cdot \sum X Y-\left(\sum X\right) \cdot\left(\sum Y\right)}{\sqrt{\left.\left(N \cdot \sum X^{2}\right)-\left(\sum X\right)^{2}\right\}\left\{\left(N \cdot \sum Y^{2}\right)-\left(\sum Y\right)^{2}\right\}}}
$$

Keterangan:

$\mathrm{r}_{\mathrm{xy}}=$ koefisien korelasi antar variabel $\mathrm{X}$ dan variabel $\mathrm{Y}$

$\mathrm{N} \quad=$ jumlah siswa

$\Sigma \mathrm{X}=$ jumlah nilai variabel $\mathrm{X}$

$\Sigma \mathrm{Y}=$ jumlah nilai variabel $\mathrm{Y}$

$\Sigma \mathrm{XY}=$ jumlah nilai perkalian variabel $\mathrm{X}$ dan $\mathrm{Y}$

$(\Sigma X)^{2}=$ jumlah nilai variabel $\mathrm{X}$ dikuadratkan

$(\Sigma Y)^{2}=$ jumlah nilai variabel $Y$ dikuadratkan

$\Sigma \mathrm{X}^{2}=$ jumlah kuadrat nilai variabel $\mathrm{X}$

$\Sigma \mathrm{Y}^{2}=$ jumlah kuadrat nilai variabel $\mathrm{Y}$.

Nilai $\mathrm{r}_{\mathrm{xy}}$ akan dikonsultasikan dengan tabel $\mathrm{r}$ product moment kriteria pengujian yaitu:

- jika $r_{x y} \geq r_{\text {tabel }}$ maka soal dikatakan valid

- jika $r_{x y}>r_{\text {tabel }}$ maka soal dikatakan tidak valid

Setelah diperoleh nilai kemudian dicocokkan dengan tabel $\mathrm{r}$ product moment.

\section{Tabel 4}

Hasil Perhitungan Validitas Angket Metode Pembelajaran Discovery

\begin{tabular}{cccc}
\hline No & r tabel & r hitung & Keterangan \\
\hline 1 & 0,300 & 0,574 & Valid \\
2 & 0,300 & 0,595 & Valid \\
3 & 0,300 & 0,559 & Valid \\
4 & 0,300 & 0,533 & Valid \\
5 & 0,300 & 0,247 & Tidak valid \\
6 & 0,300 & 0,686 & Valid \\
7 & 0,300 & 0,622 & Valid \\
8 & 0,300 & 0,504 & Valid \\
9 & 0,300 & 0,531 & Valid \\
10 & 0,300 & 0,112 & Tidak valid \\
11 & 0,300 & 0,206 & Tidak valid \\
12 & 0,300 & 0,423 & Valid \\
13 & 0,300 & 0,488 & Valid \\
14 & 0,300 & 0,137 & Tidak valid \\
15 & 0,300 & 0,506 & Valid \\
16 & 0,300 & 0,415 & Valid \\
17 & 0,300 & 0,572 & Valid \\
18 & 0,300 & 0,264 & Tidak valid \\
19 & 0,300 & 0,488 & Valid \\
20 & 0,300 & 0,517 & Valid \\
\hline
\end{tabular}




\section{c. Reliabilitas}

Reliabilitas adalah suatu alat pengukur dikatakan reliable bila alat itu dalam mengukur suatu gejala pada waktu yang berlainan senantiasa menunjukkan hasil yang sama[15]. Dalam uji reliabilitas berupa angket digunakan Kuder Richardson 20 (KR-20).

Adapun rumus KR-20 sebagai berikut:

$\mathrm{r}_{11}=\left(\frac{n}{n-1}\right)\left(\frac{s^{2}-\sum p q}{s^{2}}\right)$

Dimana:

$\mathrm{r}_{1}=$ reliabilitas angket secara keseluruhan

$\mathrm{p}=$ proporsi subjek yang menjawab item dengan benar

$\mathrm{q}=$ proporsi subjek yang menjawab item dengan salah $(\mathrm{q}=1 \mathrm{p})$

$\sum \mathrm{pq}=$ jumlah hasil perkalian antara $\mathrm{p}$ dan $\mathrm{q}$

$\mathrm{n} \quad=$ banyaknya item

$\mathrm{S} \quad=$ standar deviasi dari angket ( standar deviasi adalah akar varians)

Sedangkan di buku-buku lain n (n kecil) ini sering diganti dengan huruf $\mathrm{k}$ (k kecil), yang juga melambangkan banyaknya item. Demikian juga huruf $\mathrm{S}$ sebagai lambing standar deviasi, dituliskan SB sebagai singkatan dari kata "Simpangan Baku.” Maka rumus KR20 menjadi :

$$
\mathrm{r}_{11}=\left(\frac{\mathbb{k}}{k-1}\right)\left(\frac{S B^{2}-\sum \dot{s} q q}{S B^{2}}\right)[8]
$$

\section{Metode Analisis Data}

Dalam penelitian ini untuk mengelola data atau menganalisa data yang digunakan metode analisa kuantitatif. Dengan teknik analisis statistik. Yang di maksud dengan statistik adalah "teknik matematika dalam mengumpulkan, menyusun, memberikan, deskripsi, mengolah dan menafsirkan data kuantitatif[5].

Metode analisis di bedakan dua macam yaitu, analisis statistik analisa non statistik "Statistik berarti cara-cara ilmiah yang disiapkan untuk mengumpulkan, menyusun, menyajikan, dan menganalisa data penyelidikan yang berwujud angka-angka”[16].

Dalam penelitian ini untuk menganalisa data yang diperoleh digunakan teknik analisa statistik korelasi product moment dengan menggunakan rumus sebagai berikut:

$r_{x y}=\frac{\mathrm{n} \Sigma x y-(\Sigma x)(\Sigma y)}{\sqrt{\left\{\mathrm{n} \Sigma x^{2}-(\Sigma x)^{2}\right\}\left\{n \Sigma y^{2}-(\Sigma y)^{2}\right\}}}[8]$

Keterangan rumus:

$\mathrm{R}_{\mathrm{xy}}=$ koefisien korelasi antara $\mathrm{X}$ dan $\mathrm{Y}$

$\mathrm{Xy}=$ hasil perkalian antara $\mathrm{X}$ dan $\mathrm{Y}$

$\mathrm{X}=$ angket metode discovery

$\mathrm{Y}=$ prestasi belajar

$\mathrm{N}$ =jumlah subyek penelitian

Untuk menyajikan data menginterprestasikan data hasil penelitian, maka data analisis dengan menggunakan teknik korelasi produt moment dengan rumus angka. Rumus korelasi product moment digunakanya, penelitian ini merupakan penelitian korelasi yang dimiliki sampel yang sama sejajar, sampel yang ditarik ditentukan dengan sistem random sampling, hal ini sesuai dengan rumus korelasi product moment digunakan untuk menganalisa data interval yang memilki sampel yang sama sejajar dengan mengambil sampel secara random[10].

Kriteria pengujian dilakukan dari hasil perbandingan r-hitung dengan r-tabel. Berdasarkan hasil perbandingan tersebut akan dijadikan pedoman untu menetukan apakah hipotesis yang dirumuskan ditolak atau diterima apakah nilai hitung yang diperoleh (rxy) lebih besar atau sama dengan nilai (r) tabel pada paraf kepercayaan 5\%, maka lebih hipotesis nilai ditolak, dan sebaliknya jika hasil (rxy) lebih besar dari (r) tabel pada taraf kepercayaan 5\%, maka hipotesis nilai diterima[16].

\section{HASIL DAN PEMBAHASAN}

Pembelajaran dengan menggunakan media gambar dilaksanakan dalam 2 kali pertemuan. Pada peretemuan pertama, skenario pembelajaran yang telah direncanakan melalui model pembelajaran Discovery. Sebelum melakukan pembelajaran terlebih dahulu guru mempersiapkan kelas dalam pembelajaran seperti melakukan absensi dan melihat kebersihan kelas. Kemudian guru memberikan motivasi berupa penjajakan kesiapan belajar siswa dengan memberikan pertanyaan tentang materi yang akan diajarkan dan memberikan informasi tentang kompetensi yang akan dicapai. Kemudian guru memberikan simulasi dalam menyampaikan materi pelajaran, terlebih dahulu guru menyampaikan dan menjelaskan model pembelajaran yang digunakan, guru memberikan motivasi dan apersepsi mengenai materi yang akan dibahas. Setelah menyampaikan dan menjelaskan materi, selanjutnya guru membagi siswa menjadi 5 kelompok dan kemudian dilanjutkan dengan diskusi kelompok. Dalam melakukan diskusi guru membimbing siswa yang kesulitan dalam belajar.

Untuk lebih meningkatkan minat siswa, guru meminta perwakilan kelompok untuk mempersentasikan hasil diskusinya, sedangkan kelompok yang lain memperhatikan dan menanggapi kelompok yang melakuakan presentasi dan kemudian guru mengklarifikasi tentang materi diskusi dan guru menjelaskan konsep yang benar. Untuk mengetahui pemahaman siswa guru memberikan contoh soal dan soal latihan. Kemudian guru meminta siswa untuk menuliskan jawaban di papan tulis. Apabila ada jawaban yang masih keliru guru meminta siswa yang lain untuk memperbaiki jawaban yang salah sebelum dijawab oleh guru. Pada tahap akhir guru memberikan penghargaan kepada siswa yang berkenerja bagus dengan tujuan agar siswa semakin giat belajar dan merasa dihargai. Selanjutnya guru meminta siswa untuk menyimpulkan materi yang telah dipelajari. 
Berdasarkan hasil pengamatan dalam proses pembelajaran pada pertemuan 1 diperoleh hasil sebagai berikut.

a. Siswa masih belum terbiasa menggunakan penerapan model discovery.

b. Pembelajaran didominasi oleh siswa yang aktif saja

c. Masih ada siswa yang bermain sendiri pada saat belajar.

Kegiatan padapertemuan kedua yang dilaksanakan pada tanggal 11 Mei 2018, pada tahap ini adalah melaksanakan kegiatan pembelajaran di kelas sesuai dengan skenario pembelajaran yang telah direncanakan melalui model pembelajaran Discovery. Sebelum melakukan pembelajaran terlebih dahulu guru mempersiapkan kelas dalam pembelajaran seperti melakukan absensi dan melihat kebersihan kelas. Kemudian guru memberikan motivasi berupa penjajakan kesiapan belajar siswa dengan memberikan pertanyaan tentang materi yang akan diajarkan dan memberikan informasi tentang kompetensi yang akan dicapai. Kemudian guru memberikan simulasi dalam menyampaikan materi pelajaran, terlebih dahulu guru menyampaikan dan menjelaskan model pembelajaran yang digunakan, guru memberikan motivasi dan apersepsi mengenai materi yang akan dibahas.

Setelah menyampaikan dan menjelaskan materi, selanjutnya guru membagi siswa menjadi 5 kelompok dan kemudian dilanjutkan dengan diskusi kelompok. Dalam melakukan diskusi guru membimbing siswa yang kesulitan dalam belajar. Untuk lebih meningkatkan keaktifan siswa, guru meminta perwakilan kelompok untuk mempersentasikan hasil diskusinya, sedangkan kelompok yang lain memperhatikan dan menanggapi kelompok yang melakuakan presentasi dan kemudian guru mengklarifikasi tentang materi diskusi dan guru menjelaskan konsep yang benar. Untuk mengetahui pemahaman siswa guru memberikan contoh soal dan soal latihan.

Kemudian guru meminta siswa untuk menuliskan jawaban di papan tulis. Apabila ada jawaban yang masih keliru guru meminta siswa yang lain untuk memperbaiki jawaban yang salah sebelum dijawab oleh guru. Pada tahap akhir guru memberikan penghargaan kepada siswa yang berkenerja bagus dengan tujuan agar siswa semakin giat belajar dan merasa dihargai. Selanjutnya guru meminta siswa untuk menyimpulkan materi yang telah dipelajari. Sebelum pembelajaran diakhiri guru memberikan tugas serta meminta siswa untuk mempelajari materi yang akan dibahas pada pertemuan selanjutnya dan dipresentasikan pada pertemuan selanjutnya.

Berdasarkan hasil pengamatan dalam proses pembelajaran pada pertemua II diperoleh hasil sebagai berikut.
1) Pada saat pembelajaran siswa terlihat lebih aktif untuk mencari sendiri, semangat dan tidak merasa bosan pada saat pembelajaran.

2) Dengan penerapan inkuiri siswa lebih berani menyampaikan pendapat dan hasil penelitian yang dilakukan dan tidak takut untuk ditertawakan atau disepelekan.

3) Adanya peningkatan motivasi belajar siswa terlihat pada saat pembelajaran, tidak ada siswa yang bermain sendiri.

\section{a. Analisis Data}

Pada bagian ini peneliti akan mendeskripsikan data hasil perhitungan variael $\mathrm{x}$. Untuk mengetahui jumlah skor mentah dapat diperhitungkan dengan menggunakan rumus sebagai berikut:

Diketahui:

Jumlah butir soal $\quad: 20$

Jumlah skor maksimal setiap butir soal : 5

Jumlah skor maksimal ideal $\quad: 5 \times 20=100$

Adapun hasil perhitungan dari penyebaran angket yang peneliti lakukan dengan jumlah sampel dan jumlah skor seperti pada tabel berikut ini:

\section{Tabel 5}

Hasil Penyebaran Angket Penggunaan Teknik Discovery Dengan Media Gambar Membangkitkan Minat Belajar Siswa Tahun Pelajaran 2017/2018

\begin{tabular}{|c|c|c|}
\hline $\begin{array}{c}\text { No. } \\
\text { Responden }\end{array}$ & Nama & $\begin{array}{c}\text { Jumlah } \\
\text { (Skor) }\end{array}$ \\
\hline 1 & Maria Atun Hadiani & 66 \\
\hline 2 & Syerife Luq-Luq & 68 \\
\hline 3 & $\begin{array}{l}\text { Aulia Halimatus Sa, } \\
\text { Diah }\end{array}$ & 71 \\
\hline 4 & Maria Laura A & 72 \\
\hline 5 & Alicia Rizka Ananda & 72 \\
\hline $\begin{array}{l}5 \\
6\end{array}$ & Sofiani & 70 \\
\hline 7 & Riadatul Janah & 65 \\
\hline 8 & Titin Febrianti & 76 \\
\hline 9 & Nabila Fitri & 75 \\
\hline 10 & Srimulyani & 73 \\
\hline 11 & Salwa Anisa Patin & 69 \\
\hline 12 & Alexsandro De A & 69 \\
\hline 13 & Kiki Astuti Dewi & 72 \\
\hline 14 & Januarius Padha & 75 \\
\hline 15 & Yolanda Putri Khairna & 73 \\
\hline 16 & Juliani & 75 \\
\hline 17 & Mirantidin & 75 \\
\hline 18 & Quratul Aini & 75 \\
\hline 19 & Dastin Abdul & 75 \\
\hline 20 & Ainul Yaqin & 68 \\
\hline 21 & Irwan Supriadi & 65 \\
\hline 22 & Abi Juniardi & 72 \\
\hline 23 & Rahmanulloh & 66 \\
\hline 24 & haerudin Andikah & 76 \\
\hline 25 & Samsul Hadi & 63 \\
\hline 26 & Hasbi Hasidiqi & 63 \\
\hline 27 & Asrul Hadi & 61 \\
\hline 28 & Tanul Umul & 70 \\
\hline 29 & Sabri & 74 \\
\hline 30 & Ahmad Sukaeni & 69 \\
\hline $\begin{array}{l}30 \\
31\end{array}$ & Rahmad Agil Absori & 70 \\
\hline Jumlah $\sum$ & & 2183 \\
\hline Rata-rata & & 70,41 \\
\hline
\end{tabular}


Selanjutnya, pada bagian ini peneliti akan mendeskripsikan data variabel y yang terkait dengan minat belajar siswa. Penyelenggaraan proses pengajaran memang menuntut berbagai kemampuan yang harus dimiliki oleh pengajar serta dipraktikan baik dalam perencanaan maupun dalam pengembangannya secara nyata.

Segala bentuk kemampuan yang harus dimiliki oleh guru dimaksudkan untuk membantu para siswa dalam mengembangkan potensinya sesuai dengan tujuantujuan yang diharapkan. Oleh karena itu, untuk mengetahui hasil belajar siswa perlu dilakukan evaluasi, Dimana dari hasil evaluasi itu akan memperoleh keterangan apakah minat belajar siswa meningkat atau menurun. Berikut peneliti akan menyajikan data hasil belajar siswa kelas VII SMPN 19 Mataram:

\section{Tabel 6}

Daftar Minat Belajar Siswa Kelas VII SMPN 19 Mataram Tahun Pelajaran 2017/2018

\begin{tabular}{|c|c|c|}
\hline $\begin{array}{c}\text { No. } \\
\text { Responden }\end{array}$ & Nama & $\begin{array}{c}\text { Jumlah } \\
\text { (Skor) }\end{array}$ \\
\hline 1 & Maria Atun Hadiani & 80 \\
\hline 2 & Syerife Luq-Luq & 84 \\
\hline 3 & $\begin{array}{l}\text { Aulia Halimatus Sa, } \\
\text { Diah }\end{array}$ & 82 \\
\hline 4 & Maria Laura A & 80 \\
\hline 5 & Alicia Rizka Ananda & 81 \\
\hline 6 & Sofiani & 80 \\
\hline 7 & Riadatul Janah & 80 \\
\hline 8 & Titin Febrianti & 85 \\
\hline 9 & Nabila Fitri & 98 \\
\hline 10 & Srimulyani & 83 \\
\hline 11 & Salwa Anisa Patin & 82 \\
\hline 12 & Alexsandro De A & 80 \\
\hline 13 & Kiki Astuti Dewi & 82 \\
\hline 14 & Januarius Padha & 90 \\
\hline 15 & Yolanda Putri Khairna & 90 \\
\hline 16 & Juliani & 90 \\
\hline 17 & Mirantidin & 95 \\
\hline 18 & Quratul Aini & 95 \\
\hline 19 & Dastin Abdul & 90 \\
\hline 20 & Ainul Yaqin & 85 \\
\hline 21 & Irwan Supriadi & 80 \\
\hline 22 & Abi Juniardi & 90 \\
\hline 23 & Rahmanulloh & 88 \\
\hline 24 & haerudin Andikah & 90 \\
\hline 25 & Samsul Hadi & 85 \\
\hline 26 & Hasbi Hasidiqi & 85 \\
\hline 27 & Asrul Hadi & 80 \\
\hline 28 & Tanul Umul & 80 \\
\hline 29 & Sabri & 85 \\
\hline 30 & Ahmad Sukaeni & 83 \\
\hline 31 & Rahmad Agil Absori & 87 \\
\hline Jumlah $\sum$ & & 2645 \\
\hline Rata-rata & & 85,32 \\
\hline
\end{tabular}

Sumber Data: Diolah

b. Merumuskan Hipotesis Nihil (Ho)

Dalam rangka untuk kepentingan statistik maka hipotesis yang diajukan yang berbunyi "ada pengaruh Penggunaan Teknik Discovery Dengan Media Gambar Membangkitkan Minat Belajar SiswaVII SMPN 19 Mataram pada bidang studi PPKn terpadu tahun pelajaran 2017/2018”, akan di rubah menjadi hipotesis nihil (Ho) yang berbunyi "tidak ada pengaruh Penggunaan Teknik Discovery Dengan Media Gambar Membangkitkan Minat Belajar Siswa Kelas VII SMPN 19 Mataram pada bidang studi PPKn terpadu tahun pelajaran 2017/2018.

c. Membuat Tabel Kerja

Dalam mencari pengaruh antara kedua variabel yang diteliti yaitu Penggunaan Teknik Discovery Dengan Media Gambar Membangkitkan Minat Belajar Siswa, tentu hasilnya dimasukan kedalam tabel, maka untuk lebih jelasnya dapat dilihat pada tabel berikut:

\section{Tabel 7}

Penggunaan Teknik Discovery Dengan Media Gambar Terhadap Minat Belajar Siswa

\begin{tabular}{|c|c|c|c|c|c|c|}
\hline No & Nama & \begin{tabular}{|c|} 
Angk \\
et \\
x \\
\end{tabular} & $\begin{array}{l}\mathbf{P B} \\
\mathbf{y}\end{array}$ & $\mathbf{x}^{2}$ & $\mathbf{y}^{2}$ & xy \\
\hline 1 & $\begin{array}{l}\text { Maria Atun } \\
\text { Hadiani }\end{array}$ & 66 & 80 & 4356 & $\begin{array}{l}640 \\
0\end{array}$ & 5280 \\
\hline 2 & $\begin{array}{l}\text { Syerife } \\
\text { Luq-Luq }\end{array}$ & 68 & 84 & 4624 & 7056 & 5712 \\
\hline 3 & $\begin{array}{l}\text { Aulia } \\
\text { Halimatus } \\
\text { Sa,Diah }\end{array}$ & 71 & 82 & 5041 & 6724 & 5822 \\
\hline 4 & $\begin{array}{l}\text { Maria } \\
\text { Laura A }\end{array}$ & 72 & 80 & 5184 & $\begin{array}{l}640 \\
0\end{array}$ & 5760 \\
\hline 5 & $\begin{array}{l}\text { Alicia } \\
\text { Rizka } \\
\text { Ananda }\end{array}$ & 72 & 81 & 5184 & 6561 & 5832 \\
\hline 6 & Sofiani & 70 & 80 & 4900 & $\begin{array}{l}640 \\
0\end{array}$ & $\begin{array}{l}560 \\
0\end{array}$ \\
\hline 7 & $\begin{array}{l}\text { Riadatul } \\
\text { Janah }\end{array}$ & 65 & 80 & 4225 & $\begin{array}{l}640 \\
0\end{array}$ & $\begin{array}{l}520 \\
0\end{array}$ \\
\hline 8 & $\begin{array}{l}\text { Titin } \\
\text { Febrianti }\end{array}$ & 76 & 85 & 5776 & 7225 & $\begin{array}{l}646 \\
0\end{array}$ \\
\hline 9 & Nabila Fitri & 75 & 98 & 5625 & $\begin{array}{l}960 \\
4\end{array}$ & 7350 \\
\hline 10 & Srimulyani & 73 & 83 & 5329 & $\begin{array}{l}688 \\
9\end{array}$ & 6059 \\
\hline 11 & $\begin{array}{l}\text { Salwa } \\
\text { Anisa Patin }\end{array}$ & 69 & 82 & 4761 & 6724 & 5658 \\
\hline 12 & $\begin{array}{l}\text { Alexsandro } \\
\text { De A }\end{array}$ & 69 & 80 & 4761 & $\begin{array}{l}640 \\
0\end{array}$ & 5520 \\
\hline 13 & $\begin{array}{l}\text { Kiki Astuti } \\
\text { Dewi }\end{array}$ & 72 & 82 & 5184 & 6724 & 5904 \\
\hline 14 & $\begin{array}{l}\text { Januarius } \\
\text { Padha }\end{array}$ & 75 & 90 & 5625 & 8100 & 6750 \\
\hline 15 & $\begin{array}{l}\text { Yolanda } \\
\text { Putri } \\
\text { Khairna }\end{array}$ & 73 & 90 & 5329 & 8100 & 6570 \\
\hline 16 & Juliani & 75 & 90 & 5625 & 8100 & 6750 \\
\hline 19 & Mirantidin & 75 & 95 & 5625 & 9025 & 7125 \\
\hline 18 & $\begin{array}{l}\text { Quratul } \\
\text { Aini }\end{array}$ & 75 & 95 & 5625 & 9025 & 7125 \\
\hline 19 & $\begin{array}{l}\text { Dastin } \\
\text { Abdul }\end{array}$ & 75 & 90 & 5625 & 8100 & 6750 \\
\hline 20 & $\begin{array}{l}\text { Ainul } \\
\text { Yaqin }\end{array}$ & 68 & 85 & 4624 & 7225 & 5780 \\
\hline 21 & $\begin{array}{l}\text { Irwan } \\
\text { Supriadi }\end{array}$ & 65 & 80 & 4225 & $\begin{array}{l}640 \\
0\end{array}$ & $\begin{array}{l}520 \\
0\end{array}$ \\
\hline 22 & $\begin{array}{l}\text { Abi } \\
\text { Juniardi }\end{array}$ & 72 & 90 & 5184 & 8100 & $\begin{array}{l}648 \\
0\end{array}$ \\
\hline 23 & $\begin{array}{l}\text { Rahmanull } \\
\text { oh }\end{array}$ & 66 & 88 & 4356 & 7744 & $\begin{array}{l}580 \\
8\end{array}$ \\
\hline 24 & $\begin{array}{l}\text { haerudin } \\
\text { Andikah }\end{array}$ & 76 & 90 & 5776 & 8100 & $\begin{array}{l}684 \\
0\end{array}$ \\
\hline 25 & $\begin{array}{l}\text { Samsul } \\
\text { Hadi }\end{array}$ & 63 & 85 & 3969 & 7225 & 5355 \\
\hline
\end{tabular}




\begin{tabular}{|c|c|c|c|c|c|c|}
\hline 26 & $\begin{array}{l}\text { Hasbi } \\
\text { Hasidiqi }\end{array}$ & 63 & 85 & 3969 & 7225 & 5355 \\
\hline 27 & Asrul Hadi & 61 & 80 & 3721 & $\begin{array}{l}640 \\
0\end{array}$ & $\begin{array}{l}488 \\
0\end{array}$ \\
\hline 28 & $\begin{array}{l}\text { Tanul } \\
\text { Umul }\end{array}$ & 70 & 80 & 4900 & $\begin{array}{l}640 \\
0\end{array}$ & $\begin{array}{l}560 \\
0\end{array}$ \\
\hline 29 & Sabri & 74 & 85 & 5476 & 7225 & $\begin{array}{l}629 \\
0\end{array}$ \\
\hline 30 & $\begin{array}{l}\text { Ahmad } \\
\text { Sukaeni }\end{array}$ & 69 & 83 & 4761 & $\begin{array}{l}688 \\
9\end{array}$ & 5727 \\
\hline 31 & $\begin{array}{l}\text { Rahmad } \\
\text { Agil Absori }\end{array}$ & 70 & 87 & 4900 & 7569 & $\begin{array}{l}609 \\
0\end{array}$ \\
\hline & Jumlah & 2183 & $\begin{array}{c}264 \\
5\end{array}$ & $\begin{array}{c}15426 \\
5\end{array}$ & $\begin{array}{c}2264 \\
59\end{array}$ & $\begin{array}{c}1866 \\
32\end{array}$ \\
\hline & ta-rata & 70,41 & $\begin{array}{l}85 \\
32\end{array}$ & $\begin{array}{c}4976 \\
29\end{array}$ & $\begin{array}{l}7305 \\
, 129\end{array}$ & $\begin{array}{l}602 \\
0,38\end{array}$ \\
\hline
\end{tabular}

Sumber: Data Yang Diolah

d. Memasukan Data Kedalam Rumus $r_{x y}$

Tahap selanjutnya untuk mengetahui seberapa besar pengaruh metode discovery terhadap minat belajar siswa kelas VII SMPN 19 Mataram Tahun Pelajaran 2017/2018, Maka peneliti akan memasukan angkaangka kedalam rumus. Adapun rumus yang digunakan yaitu rumus Product Moment, rumus tersebut sebagai berikut:

Diketahui:

$\mathrm{N}: 31$

$\sum \mathrm{y}: 2645$

$\sum \mathrm{y}^{2}: 226459$

$\sum \mathrm{x}: 2183$

$\sum \mathrm{x}^{2}: 154265$

$\sum x y: 186632$

$$
\begin{aligned}
& r_{x y}=\frac{\mathrm{n} \Sigma x y-(\Sigma x)(\Sigma y)}{\sqrt{\left\{n \Sigma x^{2}-(\Sigma x)^{2}\right\}\left\{n \Sigma y 2-(\Sigma y)^{2\}}\right.}} \\
& r x y=\frac{31 \times 186632-(2183)(2645)}{\sqrt{\left\{31 x 154265-(2183)^{2}\right\}\left\{31 \times 226459-(2645)^{2}\right\}}}
\end{aligned}
$$$$
5785592-5774035
$$

$$
\begin{aligned}
r x y & =\frac{}{\sqrt{\{4782215-4765489\} 7020229-6996025\}}} \\
r x^{\circ} & =\frac{5427604-5401251}{\sqrt{16726 \times 24204}}
\end{aligned}
$$$$
r x y=\frac{11557}{20120,53}
$$$$
r x y=0,574
$$

\section{e. Menguji Signifikan Nilai $r_{x y}$}

Selanjutnya adalah menguji nilai yang diperoleh, apakah signifikan atau tidak, berdasarkan hasil perhitungan analisis data ternyata nilai hitung sebesar 0,574 dengan jumlah sampel sebanyak 31 orang siswa. Setelah angka tersebut dikonsultasikan ke dalam $r$ tabel product moment diperoleh angka sebesar o,300 pada taraf signifikansi 5\%, dengan demikian hasil perhitungan lebih besar daripada nilai yang terdapat dalam $r$ tabel yaitu $(0,574>0,300)$. Jadi hipotesis kerja
(Ha) yang diajukan yang berbunyi “Ada Pengaruh Penggunaan Teknik Discovery Dengan Media Gambar Membangkitkan Minat Belajar Siswa VII SMPN 19 Mataram Pada Bidang Studi PPKn Tahun Pelajaran 2017/2018”, diterima.

\section{f. Menarik Kesimpulan}

Berdasarkan hasil perhitungan analisis data ternyata nilai hitung sebesar o,574 dengan jumlah sampel sebanyak 31 orang siswa. Setelah $r$ tabel diperoleh angka sebesar 0,300 pada taraf signifikansi 5\%, dengan demikian hasil perhitungan lebih besar daripada nilai yang terdapat dalam $r$ tabel yaitu $(0,574>0,300)$.

Dengan demikian dapat disimpulkan bahwa hipotesis kerja (Ha) yang berbunyi, "Ada Pengaruh Penggunaan Teknik Discovery Dengan Media Gambar Membangkitkan Minat Belajar Siswa Kelas VII SMPN 19 Mataram Pada Bidang Studi PPKn Tahun Pelajaran 2017/2018”, diterima”.

\section{TEMUAN DAN DISKUSI}

Sesuai dengan hasil perhitungan, ternyata nilai perhitungan pruduct moment yang diperoleh dalam penelitian ini adalah o,574. Untuk menguji signifikan nilai $r$ yang diperoleh harus dikonsultasikan dengan tabel nilai r product moment dan nilai r product moment adalah 0,574, Jadi nilai $r$ perhitungan lebih besar dibandingkan dengan nilai $r$ table $(0,574>0,300)$, artinya hipotesa alternatif ( $\mathrm{Ha}$ ) yang berbunyi "Ada pengaruh penggunaan teknik discovery dengan media gambar membangkitkan minat belajar siswa kelas VII SMPN 19 Mataram Pada Bidang Studi PPKn Tahun Pelajaran 2017-2018”, Diterima.

Sedangkan hipotesis nihil (Ho) yang berbunyi “Tidak Ada Pengaruh Penggunaan Teknik Discovery Dengan Media Gambar Membangkitkan Minat Belajar Siswa Kelas VII SMPN 19 Mataram Pada Bidang Studi PPKn Tahun Pelajaran 2017/2018, Ditolak. Dengan diterimanya hipotesis alternatif (Ha) dan ditolaknya hipotesis nihil (Ho), maka kesimpulan analisis dalam penelitian ini adalah ada pengaruh Penggunaan Teknik Discovery Dengan Media Gambar Membangkitkan Minat Belajar Siswa Kelas VII SMPN 19 Mataram pada bidang studi PPKn terpadu tahun pelajaran 2017/2018.

Dilihat dari kenyataan hasil analisis data, lebih besar $\mathrm{r}$ dalam tabel dengan batas penolakan hipotesis $5 \%$, sehingga penelitian ini terbukti kebenarannya, maka hipotesis alternatif ( $\mathrm{Ha}$ ) diterima. Jadi koefisien korelasi (r) yang diperoleh signifikan baik pada taraf $5 \%$.

Data yang sudah diperoleh terhadap minat belajar siswa setelah menggunakan metode discovery dalam proses pembelajaran PPKn menunjukkan adanya peningkatan yang sangat baik. Hal ini juga sejalan dengan pendapat Suryo Subroto yang menjelaskan bahwa tujuan dan manfaat metode discovery antara lain sebagai suatu cara mengembangkan cara belajar siswa aktif, menemukan suatu hal baru memproses informasi 
dari berbagai sumber akademi sosial dan berfikir analisis serta mencoba memecahkan masalah yang dihadapi sendiri[17]. Dengan demikian dapat dipahami bahwa kebaikan-kebaikan yang terdapat dalam penggunaan metode discovery dengan media gambar visual adalah mengutamakan siswa dalam pembelajaran sehingga guru tidak lagi menjadi sumber belajar satusatunya bagi siswa dan dapat mengembangkan pembelajaran sesuai dengan potensi yang dimiliki siswa. Penerapan metode discovery dalam pembelajara nmenunjukkan bahwa siswa yang mengikuti pembelajaran PPKn dikelas VII B SMPN 19 Mataram memiliki minat dalam pembelajaran. Minat Belajar ini terlihat melalui empat indicator yaitu adanya peningkatan dalam merumuskan masalah, kemampuan dalam menemukan data dan informasi, kemampuan memecahkan masalah serta kemampuan menarik kesimpulan.

\section{E. SIMPULAN DAN SARAN}

Kesimpulan yang dapat disampaikan dari hasil penelitian ini adalah sebagai berikut 1) Hipotesis alternatif (Ho) yang berbunyi "Tidak ada pengaruh penggunaan teknik discovery dengan media gambar membangkitkan minat belajar siswa kelas VII SMPN 19 Mataram pada bidang studi PPKn tahun pelajaran 20172018”, Ditolak. Sedangkan (Ha) yang di ajukan berbunyi, "Adanya pengaruh penggunaan teknik discovery dengan media gambar membangkitkan minat belajar siswa kelas VII SMPN 19 Mataram pada bidang studi PPKn tahun pelajaran 2017-2018”. Diterima. 2) Hasil analisis data yang di peroleh dalam penelitian ini menunjukan bahwa nilai analisis data yang di dapat adalah 0,574 , bila dikonsultasikan dengan nilai $\mathrm{r}$ tabel dengan taraf signifikan $5 \%$, maka diperoleh nilai o,300. Jadi nilai $r$ perhitungan lebih besar dibandingkan dengan nilai $\mathrm{r}$ tabel $(0,574>0,300)$. Dengan demikian koefisien korelasi $\mathrm{r}$ diperoleh dari analisis signifikan baik pada taraf $5 \%$.

Dengan demikian disarankan bagi pemerintah untuk membuatkan regulasi tentang penggunaan media pembelajaran yang inovatif untuk meningkatkan prestasi dan minat belajar siswa, kemudian guru sebaiknya menggunakan media pembelajaran agar menciptakan pembelajaran yang menyenangkan terutama menggunakan media gambar.

\section{UCAPAN TERIMA KASIH}

Penulis mengucapkan terima kasih kepada pihak Universitas Muhammadiyah Mataram yang senantiasa memberikan saran, masukan, dan dana kepada penulis sehingga artikel ilmiah ini selesai dengan tepat waktu.

\section{DAFTAR RUJUKAN}

[1] A. Arsyad, "Media pembelajaran." Jakarta: PT Raja Grafindo Persada, 2013.

[2] R. Y. B. Gagne and L. Briggs, "Principles of
Instructional Design." Holt, Rinehart, and Winston, New York, Estados Unidos, 1975.

[3] C. Kustandi and B. Sutjipto, "Media pembelajaran manual dan digital," Bogor Ghalia Indones., 2011.

[4] Z. Aqib, "Model-model, media, dan strategi pembelajaran kontekstual (inovatif)," Bandung: yrama widya, 2013.

[5] W. Sanjaya, Perencanaan dan desain sistem pembelajaran. Kencana, 2015.

[6] I. Dina, "Ragam Alat Bantu Media Pembelajaran," 2011.

[7] Sukiman, Pengembangan Media Pembelajaran. Pedagogia, 2012.

[8] A. Suharsimi, "Prosedur penelitian suatu pendekatan praktik," Jakarta: Rineka Cipta, 2006.

[9] P. Sugiyono, Metode Penelitian Kuantitatif, Kualitatif, dan R\&D. 2013.

[10] Sugiyono, "Metode penelitian kombinasi (mixed methods)," Bandung Alf., 2015.

[11] G. M. Sudaryono and W. Rahayu, "Pengembangan Instrumen Penelitian Pendidikan," Yogyakarta Graha Ilmu, 2013.

[12] P. D. Sugiyono, "Metode Penelitian dan Pengembangan," Res. Dev. D, 2015.

[13] H. Usman, "Manajemen: teori, praktik, dan riset pendidikan," Jakarta bumi aksara, 2006.

[14] C. Narbuko and A. Achmadi, "Metodologi penelitian," Jakarta Bumi Aksara, 2007.

[15] S. Nasution, Berbagai pendekatan dalam proses belajar dan mengajar. PT. Bina Aksara, 2000.

[16] S. Hadi, "Metodologi research jilid I," Yogyakarta Andi, vol. 94, p. 95, 2004.

[17] B. Suryosubroto, "Mengenal Pengajaran di Sekolah dan Pendekatan Baru dalam Proses Belajar Mengajar,” Jakarta: Balai Pustaka, 2002. 